\title{
Trace Element Assessment in Fingernails of Adult Females
}

\section{LAURA DINES NGAU ${ }^{1}$, BOON SIONG WEE*1 \& NAZARATUL ASHIFA ABD. SALIM ${ }^{2}$}

\author{
${ }^{1}$ Resource Chemistry Programme, Faculty of Resource Science and Technology, Universiti Malaysia Sarawak, \\ 94300 Kota Samarahan, Sarawak, Malaysia; ${ }^{2}$ Malaysian Nuclear Agency, Bangi, 43000 Kajang, Selangor, \\ Malaysia \\ *Corresponding author: swboon@unimas.my
}

\begin{abstract}
Trace elements play a significant role in giving nutritional benefits to the body because they act as essential cofactors for all physiological processes. However, there are some trace elements which may bring more harm than good when entering the human body. Due to its ability to incorporate trace elements in an amount that is proportional to an individual's dietary intake and environmental exposure, human fingernails are suitable biomarkers in assessing the health status of an individual as they reflect on the trace element concentration present in the body. This study has analysed fingernail samples of 23 adult females residing in Kuching and Kota Samarahan, Sarawak, Malaysia for four elements, namely $\mathrm{Cd}, \mathrm{Cu}, \mathrm{Pb}$ and $\mathrm{Zn}$. By using flame atomic absorption spectroscopy (FAAS), the mean elemental concentrations found in fingernail samples of research participants were $171.8 \pm 33.8 \mu \mathrm{g} / \mathrm{g}$ for $\mathrm{Zn}, 27.8 \pm 14.8 \mu \mathrm{g} / \mathrm{g}$ for $\mathrm{Cu}$ and $2.64 \pm 0.94 \mu \mathrm{g} / \mathrm{g}$ for $\mathrm{Pb}$. Cd concentrations were not able to be detected as they were below the detection limits. A standard reference material, NIST 1568b Rice Flour was used to verify the methods used in elemental analysis using FAAS. Independent t-test which was used to compare the means of $\mathrm{Zn}$ and $\mathrm{Cu}$ between vegetarians and non-vegetarians showed no significant differences for both elements. Moreover, correlation analysis showed negative correlations between $\mathrm{Cu} / \mathrm{Zn}$ pair and $\mathrm{Pb} / \mathrm{Zn}$ pair, whereas significant positive correlation was obtained for $\mathrm{Cu} / \mathrm{Pb}$ pair. The overall data from this study showed good agreements with data obtained from studies in other countries. Therefore, the current data in this study represents the latest background elemental concentrations in fingernails of the residents in Kuching and Kota Samarahan, Sarawak.
\end{abstract}

Keywords: Adult females, fingernails, flame atomic absorption spectroscopy (FAAS), trace elements

Copyright: This is an open access article distributed under the terms of the CC-BY-NC-SA (Creative Commons Attribution-NonCommercialShareAlike 4.0 International License) which permits unrestricted use, distribution, and reproduction in any medium, for non-commercial purposes, provided the original work of the author(s) is properly cited.

\section{INTRODUCTION}

Trace elements are known as dietary minerals which are needed in small quantities for ensuring normal physiological functions in the body of living organisms (Strachan, 2010). Trace elements are those which constitutes less than $0.01 \%$ of body mass. Being structural constituents of enzymes or cofactors, they play vital roles in the prevention of nutritional deficiencies, antioxidant defence, immune functions, regulation of gene expression and in the prevention of chronic diseases. Although most trace elements present in human bodies are essential elements produced naturally by the body itself, it is also possible for these elements to be taken in from the external environment. This leads to the increase in trace element concentrations in the body. Other than that, the uptake of environmental elements, such as heavy metals, into the human body is possible by three main routes, namely dermal absorption, inhalation and ingestion. Thus, upon high exposure to possible sources of environmental elements and heavy metals, the human body may contain high concentrations of trace elements which can be toxic and lead to negative health effects to the exposed individual (Esteban \& Castano, 2008; Parizanganeh, Zamani, Bijnavand \& Taghilou, 2014). Human biomonitoring (HBM) is defined as a scientific technique that allows researchers to investigate how much of environmental substances have entered the human body, besides looking at how these exposures vary over a certain period of time. The biological samples, such as blood, breastmilk, saliva, urine and nails, are collected, analysed and are then compared with suitable reference values in order to assess exposure and health risk of the exposed subjects (Angerer, Aylward, Hays, Heinzow \& Wilhelm, 2011; Esteban \& Castano, 2008; Waseem \& Arshad, 2016). In this study, fingernail samples were chosen mainly due to its easy sample collection and storage, besides having the advantage of reflecting elemental concentrations in the body from a period of 12 to 28 months (Li et al., 2012).

To the best of current knowledge, there has yet to be any published research on the proposed study area, namely Kuching and Kota Samarahan, Sarawak, Malaysia. As mentioned in Li et al. (2012), the scientific data for elemental nail concentrations are still limited even with the findings obtained from previous studies throughout 
the years. It was further reported that most of the previous researches relied on data findings from other studies which were scattered worldwide. Therefore, the objective of this study is to determine the concentrations of cadmium $(\mathrm{Cd})$, copper $(\mathrm{Cu})$, lead $(\mathrm{Pb})$ and zinc $(\mathrm{Zn})$ in fingernails of adult females. These results were also compared with literature values from other countries.

\section{MATERIALS \& METHODS}

\section{Sample Collection and Washing}

A total of 23 sets of fingernail samples were collected from healthy adult females who reside in Kuching or Kota Samarahan, Sarawak areas. These research participants were in the age range of 18 to 60 years old, in which the majority were university students. Among these participants, three of them were vegetarians whereas none were smokers. Fingernail samples (from 10 fingers) were collected from the participants using clean stainless-steel clippers and were stored in polyethylene bags. A minimum of three samples were collected from each participant, commonly at an interval of two to three weeks. Each individual was given a survey form, which was used to obtain required information including age, occupation, area of stay and her dietary habits, specifically whether she was a vegetarian or non-vegetarian and smoker or non-smoker.

Each batch of fingernail sample was washed using the methods reported in Wee and Ebihara (2017). Upon transferring samples into a beaker, acetone was added just enough to cover the nails and left aside for 20 minutes. This step was then repeated with deionized water for 20 minutes, followed by another washing with acetone for another 20 minutes. After washing, fingernail samples were transferred into a crucible before being placed in the drying oven $\left(66^{\circ} \mathrm{C}\right)$ for 30 minutes. The samples were fully dried when nails have achieved constant weight (Nyambura, 2012).

\section{Acid Digestion and Analysis}

Prior to acid digestion of fingernail samples, the weight of each set of nail sample was determined first. The acid digestion of samples was done using nitric acid, $\mathrm{HNO}_{3}$ in a fume chamber. A hot plate was used as the heating platform. Next, $5 \mathrm{~mL}$ of $65 \% \mathrm{HNO}_{3}$ was added into each beaker containing nail samples, before heating the beakers at medium temperature. As nail samples were digested, light to dark yellow solution were formed. The sample solutions were left to digest and evaporate until about less than $1 \mathrm{~mL}$ of solution was left. Each set of samples averagely took $1 \mathrm{hr}$ to $1 \mathrm{hr} 45$ minutes for digestion. When the sample had cooled down, they were diluted with $20 \mathrm{~mL}$ of deionized water. They were then filtered directly into respective sample bottles using $0.01 \mathrm{~mm}$ filter papers. When this step was done, the sample bottles were sealed tightly and kept in the refrigerator at $4{ }^{\circ} \mathrm{C}$ until FAAS analysis. These samples were kept not longer than 48 hours before analysis.

\section{Analysis of Standard Reference Material, NIST 1568b Rice Flour}

In order to ascertain the accuracy of method used in this experiment, the analysis of NIST 1568b Rice Flour was performed using the FAAS. A $0.5 \mathrm{~g}$ of the NIST $1568 \mathrm{~b}$ Rice Flour were used, with the preparation methods similar to that of fingernail samples.

\section{Statistical Calculation and Analysis}

The Limit of Detection (LOD) was calculated using the formula LOD $=X_{b l}+3 S_{b l}$ where $X_{b l}$ is the mean concentration of sample blanks $(n=3)$ and $S_{\mathrm{bl}}$ is the standard deviation of the sample blanks (Shrivastava \& Gupta, 2011). Moreover, the results obtained from this study were analysed using IBM SPSS Statistics version 23.0. Firstly, the independent t-test was used to compare the means of each element between vegetarian and nonvegetarian participants. Secondly, correlation analysis was done to observe the relationship between the elements assessed in this study.

\section{RESULTS \& DISCUSSION \\ Analytical Quality Control}

Table 1 shows the mean concentrations and standard deviations of blank samples used, including the experimental LOD.

Table 1. The experimental detection limits of FAAS in this study.

\begin{tabular}{cccc}
\hline Element & $\boldsymbol{\lambda}(\mathbf{n m})$ & $\begin{array}{c}\text { Mean concentration of blank } \\
\text { samples }(\boldsymbol{\mu g} / \mathbf{g})\end{array}$ & $\begin{array}{c}\text { Limit of Detection, LOD } \\
(\boldsymbol{\mu g} / \mathbf{g})\end{array}$ \\
\hline $\mathbf{Z n}$ & 213.9 & $0.419 \pm 0.245$ & 1.15 \\
$\mathbf{C u}$ & 324.8 & $0.413 \pm 0.272$ & 1.23 \\
$\mathbf{P b}$ & 217.0 & $0.016 \pm 0.059$ & 0.19 \\
$\mathbf{C d}$ & 228.8 & $0.079 \pm 0.036$ & 0.19 \\
\hline
\end{tabular}


The results for $\mathrm{Cd}, \mathrm{Cu}, \mathrm{Pb}$ and $\mathrm{Zn}$ concentrations in NIST $1568 \mathrm{~b}$ Rice Flour are as shown in Table 2, alongside the NIST certified values. These elemental concentrations were expressed as mean \pm standard deviation of three independent measurements.

Table 2. Comparison of elemental concentrations in this work with NIST 1568b certified values.

\begin{tabular}{cccc}
\hline \multirow{2}{*}{ Element } & \multicolumn{2}{c}{ NIST 1568b Rice Flour (in $\boldsymbol{\mu g} / \mathbf{g})$} & \multirow{2}{*}{ p- value } \\
\cline { 2 - 3 } & Experimental Concentration & Certified Concentration & \\
\hline Zn & $21.69 \pm 1.32$ & $19.42 \pm 0.26$ & 0.25 \\
Cu & $2.39 \pm 0.04$ & $2.35 \pm 0.16$ & 0.40 \\
Pb & - & $0.008 \pm 0.003$ & - \\
Cd & - & $0.0224 \pm 0.0013$ & - \\
\hline aाषb
\end{tabular}

\footnotetext{
Value less than instrument experimental detection limit.
}

The values observed between certified and experimental concentrations in this work showed good agreements for $\mathrm{Cu}$ and $\mathrm{Zn}$, however the concentrations of $\mathrm{Cd}$ and $\mathrm{Pb}$ were below the experimental detection limit of FAAS. The values for $\mathrm{Cu}$ and $\mathrm{Zn}$ did not show any significant differences from certified concentrations as both p-values, which were obtained from one-sample t-test, were more than 0.05. In a report by Gholami, Behkami, Zain and Bakirdere (2016), it was stated that the values obtained for $\mathrm{Cd}, \mathrm{Cu}$, and $\mathrm{Zn}$ were $0.0219 \pm 0.0012 \mu \mathrm{g} / \mathrm{g}, 2.34 \pm 0.09 \mu \mathrm{g} / \mathrm{g}$ and $18.72 \pm 0.51 \mu \mathrm{g} / \mathrm{g}$ respectively for NIST $1568 \mathrm{~b}$ Rice Flour. The values obtained in this study were in good agreement with the certified values and those reported in Gholami et al. (2016). Thus, results obtained are acceptable for further discussions.

\section{Elemental Concentrations in Fingernails}

In this study, $\mathrm{Cu}$ and $\mathrm{Zn}$ could be detected in all fingernail samples, $\mathrm{Pb}$ only in seven samples whereas $\mathrm{Cd}$ concentrations were below the detection limits for all samples. Among the three elements detected, it was observed that $\mathrm{Zn}$ was the most abundant element with mean value of $171.8 \pm 33.8 \mu \mathrm{g} / \mathrm{g}$, followed by $\mathrm{Cu}$ with mean concentration of $27.8 \pm 14.8 \mu \mathrm{g} / \mathrm{g}$. Meanwhile, $\mathrm{Pb}$ had a mean value of $2.64 \pm 0.94 \mu \mathrm{g} / \mathrm{g}$. The overall elemental concentration of all samples are shown in Table 3. The standard deviation values used in these results were based on the triplicates of fingernail samples obtained, except for the case of P22 and P23 in which their standard deviations were based on two sets of fingernail samples.

The results of $\mathrm{Zn}$ concentrations in this study were in accordance to previous findings from literatures. As reported in Chaudhary, Ehmann, Rengan and Markesbery (1995), the Zn concentrations were found to have a mean value of $147.0 \mu \mathrm{g} / \mathrm{g}$, which was lower than that of this study. The $\mathrm{Zn}$ concentrations for three vegetarian participants were $145.6 \pm 27 \mu \mathrm{g} / \mathrm{g}, 132.8 \pm 26.8 \mu \mathrm{g} / \mathrm{g}$ and $207.7 \pm 51.7 \mu \mathrm{g} / \mathrm{g}$. Other than that, the mean $\mathrm{Zn}$ concentrations of adult females in Kuching and Kota Samarahan were found to be lower than that of adult females in North, East and West Sudan, in which the Zn concentrations were reported to be $638 \pm 172 \mu \mathrm{g} / \mathrm{g}, 667 \pm 127 \mu \mathrm{g} / \mathrm{g}$ and $885 \pm$ $127 \mu \mathrm{g} / \mathrm{g}$ respectively. As further explained in Ebrahim et al. (2011), one of the factors contributing to the high concentrations in Sudan was the dietary habits of people in these areas. Comparing the results of $\mathrm{Zn}$ levels in this study with that in other countries, the minimum range for $\mathrm{Zn}$ was not as low as the results reported. For instance, Rodushkin and Axelsson (2000) indicated in their study on individuals in Sweden that the minimum $\mathrm{Zn}$ concentration was $80.0 \mu \mathrm{g} / \mathrm{g}$, while Samantha, Sharma, Roychowdhury and Chakraborti (2004) reported minimum Zn concentrations of $72.8 \mu \mathrm{g} / \mathrm{g}$ in India and $48.2 \mu \mathrm{g} / \mathrm{g}$ in Nigeria (Olabanji et al., 2005).

King, Shames and Woodhouse (2000) mentioned that zinc concentrations in normal human body occurs in the range of $107 \mu \mathrm{g} / \mathrm{g}$ to $231 \mu \mathrm{g} / \mathrm{g}$. If zinc concentrations are constantly below $22.0 \mu \mathrm{g} / \mathrm{g}$ for a long period of time, that particular individual may be having zinc deficiency, which leads to various diseases. However, a report by Kanabrocki, Kanabrocki, Greco, Kaplan and Oester (1979) has shown that the Zn concentrations had a range of $12.0 \mu \mathrm{g} / \mathrm{g}$ to $184 \mu \mathrm{g} / \mathrm{g}$ (mean value of $88 \mu \mathrm{g} / \mathrm{g}$ ) for individuals who were affected by beriberi. In contrast, $\mathrm{Zn}$ concentrations in this work were reported to be apparently higher than the normal range of $93.0 \mu \mathrm{g} / \mathrm{g}$ to $129.0 \mu \mathrm{g} / \mathrm{g}$ as stated in Mahler, Scott, Walsh and Haynie (1970). In Mahler et al. (1970), elevated concentration of Zn levels was found in patients who were affected by diseases such as uraemia, which had a mean concentration of 478.0 $\mu \mathrm{g} / \mathrm{g}$, and patients who were undergoing the dialysis treatment, which had a mean concentration of $445.0 \mu \mathrm{g} / \mathrm{g}$. Therefore, it can be concluded that the levels of $\mathrm{Zn}$ in fingernail samples of all participants in this study were within the recommended range, besides not being subjected to any $\mathrm{Zn}$ deficiency or toxicity.

The $\mathrm{Cu}$ concentrations of the three vegetarian participants in this study were $18.1 \pm 0.51 \mu \mathrm{g} / \mathrm{g}, 23.1 \pm 3.16 \mu \mathrm{g} / \mathrm{g}$ and $38.8 \pm 4.57 \mu \mathrm{g} / \mathrm{g}$ respectively. These values were comparably higher than that of $\mathrm{Cu}$ concentrations obtained among vegetarians of similar age group which were reported in Mehra and Juneja (2005), which observed values 
of $8.96 \pm 1.35 \mu \mathrm{g} / \mathrm{g}$. Based on literature values of $\mathrm{Cu}$ from other countries, most of the concentrations found present in fingernail samples were less than $10 \mu \mathrm{g} / \mathrm{g}$. For example, Nowak and Chmielnicka (2000) reported that Polish volunteers had mean $\mathrm{Cu}$ concentrations of $7.0 \mu \mathrm{g} / \mathrm{g}$ in their fingernails, Canada volunteers gave mean values of $9.2 \mu \mathrm{g} / \mathrm{g}$ (Li et al., 2012), Saudi Arabia adults had values of $9.01 \pm 1.03 \mu \mathrm{g} / \mathrm{g}$ (Momen, Khalid, Elsheikh \& Ali, 2015) and the participants in Japan gave results of $5.18 \pm 1.72 \mu \mathrm{g} / \mathrm{g}$ (Wee \& Ebihara, 2017). When the results of this work were compared with the study done in Malaysia previously, Cu levels in nails of volunteers in Kuching and Kota Samarahan were very high. Ghazali et al. (2013), which researched on trace element concentrations in the nails of elderly people living in FELDA settlement in Selangor, found out that $\mathrm{Cu}$ concentrations were $4.81 \pm$ $1.16 \mu \mathrm{g} / \mathrm{g}$.

Table 3. Elemental concentrations (in $\mu \mathrm{g} / \mathrm{g}$ dry mass) in fingernails of adult females. Vegetarian participants were marked with asterisk $(*)$.

\begin{tabular}{|c|c|c|c|c|}
\hline \multirow{2}{*}{ Participants } & \multicolumn{4}{|c|}{ Concentrations (in $\mu \mathrm{g} / \mathrm{g}$ dry mass) } \\
\hline & $\mathbf{Z n}$ & $\mathbf{C u}$ & $\mathbf{P b}$ & Cd \\
\hline P1 & $161.8 \pm 12.5$ & $49.09 \pm 1.96$ & $<0.19$ & $<0.19$ \\
\hline $\mathbf{P 2}$ & $220.2 \pm 43.2$ & $39.41 \pm 5.52$ & $<0.19$ & $<0.19$ \\
\hline P3 & $196.9 \pm 1.8$ & $22.18 \pm 3.14$ & $<0.19$ & $<0.19$ \\
\hline P4 & $202.5 \pm 69.3$ & $39.23 \pm 4.86$ & $<0.19$ & $<0.19$ \\
\hline P5 & $159.6 \pm 39.4$ & $19.73 \pm 4.89$ & $<0.19$ & $<0.19$ \\
\hline P6 & $169.8 \pm 25.7$ & $15.30 \pm 1.55$ & $<0.19$ & $<0.19$ \\
\hline P7 & $170.1 \pm 22.4$ & $24.50 \pm 3.27$ & $2.48 \pm 0.04$ & $<0.19$ \\
\hline P8 & $197.1 \pm 9.5$ & $8.37 \pm 0.55$ & $<0.19$ & $<0.19$ \\
\hline P9 & $239.7 \pm 46.6$ & $10.04 \pm 1.56$ & $<0.19$ & $<0.19$ \\
\hline P10 & $152.9 \pm 7.5$ & $6.99 \pm 1.11$ & $<0.19$ & $<0.19$ \\
\hline P11 & $167.0 \pm 9.7$ & $6.33 \pm 1.91$ & $<0.19$ & $<0.19$ \\
\hline P12 & $143.2 \pm 19.4$ & $7.92 \pm 1.43$ & $<0.19$ & $<0.19$ \\
\hline P13* & $145.6 \pm 27.0$ & $38.78 \pm 4.57$ & $<0.19$ & $<0.19$ \\
\hline P14 & $206.9 \pm 36.4$ & $36.67 \pm 2.02$ & $<0.19$ & $<0.19$ \\
\hline P15* & $132.8 \pm 26.8$ & $18.09 \pm 0.51$ & $2.51 \pm 0.04$ & $<0.19$ \\
\hline P16 & $134.5 \pm 17.8$ & $31.29 \pm 1.75$ & $4.04 \pm 0.41$ & $<0.19$ \\
\hline P17 & $115.7 \pm 8.9$ & $55.39 \pm 1.96$ & $3.66 \pm 0.60$ & $<0.19$ \\
\hline P18 & $185.5 \pm 7.3$ & $35.84 \pm 3.22$ & $2.10 \pm 0.03$ & $<0.19$ \\
\hline P19 & $197.2 \pm 42.7$ & $48.84 \pm 2.01$ & $<0.19$ & $<0.19$ \\
\hline P20 & $123.9 \pm 7.0$ & $33.93 \pm 1.48$ & $1.25 \pm 0.24$ & $<0.19$ \\
\hline $\mathbf{P 2 1}$ & $129.6 \pm 0.5$ & $42.53 \pm 6.14$ & $<0.19$ & $<0.19$ \\
\hline P22* & $207.7 \pm 51.7$ & $23.09 \pm 3.16$ & $<0.19$ & $<0.19$ \\
\hline $\mathbf{P 2 3}$ & $192.0 \pm 4.5$ & $25.70 \pm 2.74$ & $2.48 \pm 0.25$ & $<0.19$ \\
\hline
\end{tabular}

However, there were other studies which have found high levels of $\mathrm{Cu}$ in the human body which also used fingernails as biomarkers. Ashraf, Jaffar and Mohammad (1994) have reported a mean Cu concentration of 22.4 $\mu \mathrm{g} / \mathrm{g}$, whereas in the following year, another publication obtained a result of $20.8 \mu \mathrm{g} / \mathrm{g}$ (Ashraf, Jaffar, Anwer \& Ehsan, 1995). This particular study was done among occupationally non-exposed Russian adults who lived in urban areas. The results of high $\mathrm{Cu}$ levels were also supported by Ebrahim et al. (2011), whereby healthy individuals of Sudan gave mean $\mathrm{Cu}$ concentrations of $73.8 \mu \mathrm{g} / \mathrm{g}$. According to Bost et al. (2015), there are still uncertainties in the medical field regarding the $\mathrm{Cu}$ reference values for humans. It is known that the daily intakes of $\mathrm{Cu}$ below $0.8 \mathrm{mg} /$ day commonly leads to $\mathrm{Cu}$ deficiency, whereas the intakes of more than $2.4 \mathrm{mg} / \mathrm{day}$ would 
lead to consistent net gains of this element in the body. Playing an important role in the synthesis of haemoglobin, carbohydrate metabolism and acting as a co-factor for many redox enzymes, $\mathrm{Cu}$ levels in the body is agreed to be highly dependent on the dietary intakes of each individual. For example, meat products such as liver, beef, and kidney are known to have high Cu levels in the range of $2.1 \mathrm{mg} / \mathrm{kg}$ to $4.3 \mathrm{mg} / \mathrm{kg}$. This comes to show in cereal products, vegetables and seafood whereby the $\mathrm{Cu}$ concentrations present ranges in about $0.6 \mathrm{mg} / \mathrm{kg}$ to $16.6 \mathrm{mg} / \mathrm{kg}$, $0.48 \mathrm{mg} / \mathrm{kg}$ to $16.0 \mathrm{mg} / \mathrm{kg}$, and $0.3 \mathrm{mg} / \mathrm{kg}$ to $16.0 \mathrm{mg} / \mathrm{kg}$ respectively. Besides dietary habits, this element is also able to spread through the intake of birth control pills or nutritional deficiencies supplements, as well as spread environmentally, such as through hot water pipes, construction areas and dusts from mining sites (Ashish, Neeti \& Himanshu, 2013).

Lead, $\mathrm{Pb}$ is a type of heavy metal which is commonly present in $8 \mathrm{mg} / \mathrm{kg}$ to $20 \mathrm{mg} / \mathrm{kg}$ in the earth's crust. It is not an essential element in the human body, therefore, when someone is highly exposed to this element for long periods of time, he or she may be said to be contaminated with lead (WHO, 2015). In this study, the LOD for the analysis of $\mathrm{Pb}$ was calculated as $0.19 \mu \mathrm{g} / \mathrm{g}$. The results of $\mathrm{Pb}$ in this study had an overall mean value of $2.64 \pm 0.94 \mu \mathrm{g} / \mathrm{g}(n$ $=7$ ), in which all participants were non-vegetarians except for one. Moreover, the results obtained in this experiment were in accordance to the available $\mathrm{Pb}$ concentrations which were found in similar literatures as discussed below. In a fingernail analysis study by Kanabrocki et al. (1979), the results of Pb for healthy adult female ages between 23 years old to 60 years old were in the range of $1.7 \mu \mathrm{g} / \mathrm{g}$ to $24.0 \mu \mathrm{g} / \mathrm{g}$. Moreover, other similar studies have had low $\mathrm{Pb}$ concentrations of $1.35 \mu \mathrm{g} / \mathrm{g}$ to $1.98 \mu \mathrm{g} / \mathrm{g}$ in non-smoking adults (Afridi et al., 2008), $0.72 \mu \mathrm{g} / \mathrm{g}$ in healthy adult volunteers (Goulle et al., 2009) and $1.046 \mu \mathrm{g} / \mathrm{g}$ in occupationally non-exposed Russion adults (Skalny et al., 2015). These examples indicated that Pb concentration in this study was considered as low levels.

However, when the results of $\mathrm{Pb}$ in adult females in this study were compared to that of another Malaysian study, the results in the latter research was reported to be higher, which was $6.2 \pm 5.2 \mu \mathrm{g} / \mathrm{g}$ (Ghazali et al., 2012). This may be due to the occupational exposure of research participants involved in their study. Since they were taking nail samples from adults working in an agricultural farm, they might have been exposed to high levels of pesticides and fertilizers, which caused the higher $\mathrm{Pb}$ concentrations.

Although high $\mathrm{Pb}$ concentrations are constantly related to toxicity in the human body, a research by Mehra and Juneja (2005) had obtained Pb levels of $20.21 \pm 6.17 \mu \mathrm{g} / \mathrm{g}$ in their control group. This control group were healthy individuals, in which the obtained $\mathrm{Pb}$ values were used to compare with the $\mathrm{Pb}$ levels obtained from nail samples of individuals with health disorders. Those with health disorders such as skin disease, hypotension, hypertension and diabetes actually shown variations of $\mathrm{Pb}$ concentration results. These results were either higher than or lower than the results of healthy individuals. In another report, it was indicated that high $\mathrm{Pb}$ concentrations in fingernail samples were only found in those who were exposed for long periods of time through their occupation. The results in Abdulrahman, Akan, Chellube and Waziri (2012) have proven that workers of a welding factory had very high $\mathrm{Pb}$ levels, $19.45 \mu \mathrm{g} / \mathrm{g}$ to $55.67 \mu \mathrm{g} / \mathrm{g}$. Due to this, the workers in this particular research were said to be contaminated with $\mathrm{Pb}$, in which this situation may lead to negative health effects. Through comparison with literature, $\mathrm{Pb}$ concentrations in fingernail samples show variations depending on the health status as well as the occupationalexposure of individuals. This can be seen through the concentrations of $\mathrm{Pb}$ among adult females in Kuching and Kota Samarahan which were still within the acceptable range. The concentrations showed that they were in good agreements to literature values of healthy and non-smoking participants (Afridi et al., 2008; Goulle et al., 2009), besides having the results in this study not as high as $\mathrm{Pb}$ concentrations found in occupationally-exposed individuals (Abdulrahman et al., 2012; Ghazali et al., 2012; Skalny et al., 2015).

\section{Statistical Analysis}

In this study, the independent t-test was done for comparing the means of $\mathrm{Zn}$ and $\mathrm{Cu}$ between vegetarians and nonvegetarian participants. $\mathrm{Pb}$ was not analysed as there were insufficient information for any comparison to be done. Since there were only three vegetarian participants who were in the age range of $20-29$ years old, their results were only compared with the results of non-vegetarians in similar age group. The $\mathrm{Cu}$ and $\mathrm{Zn}$ concentrations in vegetarian and non-vegetarian participants were compared as both elements were reported to have significant differences between these two groups (Hunt, 2003; Yoshida, Ogi, \& Iwashita, 2011). Yoshida et al. (2011) mentioned that $\mathrm{Cu}$ intake in vegetarian women were slightly higher than non-vegetarian women as $\mathrm{Cu}$ is present in higher content in vegetables. Additionally, Hunt (2003) explained that since $\mathrm{Zn}$ is present in higher content in meats, the absorption of $\mathrm{Zn}$ in vegetarians were considerably lower.

In this study, it was found that there were no significant differences between $\mathrm{Zn}$ and $\mathrm{Cu}$ concentrations present in vegetarian and non-vegetarian nail samples, with the $\mathrm{p}$-value being 0.294 and 0.133 respectively. These results differed from those reported in Mehra and Juneja (2005) as in their research, there were significant differences between $\mathrm{Zn}$ concentrations of these two groups for both $\mathrm{Zn}$ and $\mathrm{Cu}$. 
According to Samantha et al. (2004), correlation coefficients are used to show potential relationships or any interactions between two elements which are assessed in fingernail samples. The correlation coefficients, in this case, the Pearson correlation coefficient, was used and represented as a correlation matrix which is shown in Table 4.

Table 4. Correlation matrix among elemental concentrations in fingernail samples. The number in bold indicates that the concentrations are significant at $\mathrm{p}=0.05$.

\begin{tabular}{cccc}
\hline & $\mathbf{Z n}$ & $\mathbf{C u}$ & $\mathbf{P b}$ \\
\hline $\mathbf{Z n}$ & 1 & & \\
$\mathbf{C u}$ & -0.155 & 1 & \\
$\mathbf{P b}$ & -0.358 & $\mathbf{0 . 4 4 5}$ & 1 \\
\hline
\end{tabular}

A significant positive correlation was observed between $\mathrm{Cu}$ and $\mathrm{Pb}$, in which $r=0.445$. This showed that although $\mathrm{Pb}$ is a heavy metal which might become toxic to the body, there was a good balance between these two elements in the fingernail samples of adults in this study. Next, the pair of $\mathrm{Zn}$ with $\mathrm{Cu}$, and $\mathrm{Zn}$ with $\mathrm{Pb}$ showed negative correlations of $r=-0.155$ and $r=-0.358$ respectively. Both pairs showed no significant differences at $\mathrm{p}=0.05$. The negative correlation between $\mathrm{Zn}$ and $\mathrm{Cu}$ was opposite to the results reported in Wee and Ebihara (2017), whereby their research has indicated that $\mathrm{Zn}$ and $\mathrm{Cu}$ had positive correlations. Unlike the explanations made in this literature, this study showed that $\mathrm{Zn}$ and $\mathrm{Cu}$ were not in good balance among the research participants. Instead, present results showed the presence of either one of these elements in high amounts might cause the deficiency of the other (Lech \& Sadlik, 2007).

As for the pair of $\mathrm{Zn}$ and $\mathrm{Pb}$, the results of this study were opposite to that in Mehra and Thakur (2016), in which the $\mathrm{Zn} / \mathrm{Pb}$ pair gave strong positive correlation among their research volunteers who were healthy and acted as control group. However, based on Fadayon, Abdollahi, Nia and Ostovar (2013), the excess and deficiency of some essential trace elements like $\mathrm{Zn}$, are more likely to be affected by the presence of heavy metals like $\mathrm{Pb}$ and $\mathrm{Cd}$. It was further explained that heavy metals in excessive amounts in the body damages organs and disrupts the physiological homeostasis, indirectly disrupting trace element concentrations as well. Therefore, the results of this study are obviously different from studies done in other countries in terms of the correlation between $\mathrm{Zn}$ and $\mathrm{Pb}$.

\section{CONCLUSION}

In this study, fingernail samples from 23 healthy adult females from Kuching and Kota Samarahan had been collected and analysed. The sample collection and preparation had been done accordingly, followed by the analysis of $\mathrm{Cd}, \mathrm{Cu}, \mathrm{Pb}$ and $\mathrm{Zn}$ using FAAS. Zn was found to be higher than other elements in all fingernail samples, with mean concentration of $171.8 \pm 33.8 \mu \mathrm{g} / \mathrm{g}$, followed by $\mathrm{Cu}$ with mean value of $27.8 \pm 14.8 \mu \mathrm{g} / \mathrm{g}$. Among the seven samples in which $\mathrm{Pb}$ was detected, the mean concentration was $2.64 \pm 0.94 \mu \mathrm{g} / \mathrm{g}$. Cd levels were too low to be detected by FAAS. Comparing $\mathrm{Zn}$ and $\mathrm{Cu}$ concentrations between vegetarian and non-vegetarian participants, no significant differences were found through the independent t-test. Nevertheless, significant correlation was observed for $\mathrm{Cu} / \mathrm{Pb}$ pair whereas the analysis showed negative correlations for other pairs. The results obtained from this research could serve in providing baseline reference values for future studies for the people in Kuching and Kota Samarahan, Sarawak, Malaysia.

\section{ACKNOWLEDGEMENT}

The authors thank Mr. Tomy Bakeh for guidance on FAAS and the Faculty of Resource Science and Technology, UNIMAS for supporting this project. The authors would also like to thank the participants for their willingness in providing their fingernail samples.

\section{REFERENCES}

Abdulrahman, F. I., Akan, J. C., Chellube, Z. M., \& Waziri, M. (2012). Levels of heavy metals in human hair and nail samples from Maiduguri Metropolis, Borno State, Nigeria. World Environment, 2(4), 81-89.

Afridi, H. I., Kazi, T. G., Kazi, N., Jamali, M. K., Arain, M. B., Jalbani, N., Baig, J. A., \& Sarfraz, R. A. (2008). Evaluation of status of toxic metals in biological samples of diabetes mellitus patients. Diabetes Research and Clinical Practice, 80, 280-288.

Ashish, B., Neeti, K., \& Himanshu, K. (2013). Copper toxicity: A comprehensive study. Research Journal of Recent Sciences, 2, 58-67.

Ashraf, W., Jaffar, M., \& Mohammad, D. (1994). Age and sex dependence of selected trace metals in scalp hair of urban population of Pakistan. Science of Total Environment, 151, 227-233. 
Ashraf, W., Jaffar, M., Anwer, K., \& Ehsan, U. (1995). Age- and sex-based comparative distribution of selected metals in the scalp hair of an urban population from two cities in Pakistan. Environmental Pollution, 87, 6164.

Angerer, J., Aylward, L. L., Hays, S. M., Heinzow, B., \& Wilhelm, M. (2011). Human biomonitoring assessment values: Approaches and data requirements. International Journal of Hygiene and Environmental Health, 214, 348-360.

Bost, M., Houdart, S., Oberli, M., Kalonji, E., Huneau, J. F., \& Margaritis, I. (2015). Dietary copper and human health: Current evidence and unresolved issues. Journal of trace elements in medicine and biology, 35, 107115.

Chaudhary, K., Ehmann, W. D., Rengan, K., \& Markesbery, W. R. (1995). Trace element correlations with age and sex in human fingernails. Journal of Radioanalytical and Nuclear Chemistry, 195(1), 51-56.

Ebrahim, A. M., Eltayeb, M., Benker, B., Grill, P., Attahir, M., Osman, A., Elsadig, M., \& Michalke, B. (2011). Study on some trace elements contents in serum and nail samples obtained from Sudanese subjects. Biological Trace Element Research, 144, 225-233.

Esteban, M., \& Castano, A. (2008). Non-invasive matrices in human biomonitoring: A review. Environment International, 35, 438-449.

Fadayon, F., Abdollahi, A., Nia, S. R., \& Ostovar, R. (2013). Relationship between the level of zinc, lead, cadmium, nickel and chromium in hair of people with diabetes. Web of Conferences, 1. doi.org/10.1051/e3sconf/20130141012

Ghazali, A. R., Kamarulzaman, F., Normah, C. D., Ahmad, M., Ghazali, S. E., Ibrahim, N., \& Razali, R. (2013). Levels of metallic elements and their potential relationships to cognitive function among elderly from Federal Land Development Authority (FELDA) settlement in Selangor Malaysia. Biological Trace Element Research, 153, 16-21.

Ghazali, A. R., Razak, N. E. A., Othman, M. S., Othman, H., Ishak, I., Lubis, S. H., Mohammad, N., Hamid, Z., A., Harun, Z., Kamarulzaman, F., \& Abdullah, R. (2012). Study of heavy metal levels among farmers of Muda Agricultural Development Authority, Malaysia. Journal of Environmental and Public Health, 2012. doi:10.1155/2012/758349

Gholami, M., Behkami, S., Zain, S. M., \& Bakirdere, S. (2016). A simple design for microwave assisted digestion vessel with low reagent consumption suitable for food and environmental samples. Scientific Reports, 6. doi: 10.1038/srep37186

Goulle, J. P., Saussereau, E., Mahieu, L., Bouige, D., Groenwont, D., Guerbet, M., \& Lacroix, C. (2009). Application of inductively coupled plasma mass spectrometry mulitielement analysis in fingernail and toenail as a biomarker of metal exposure. Journal of Analytical Toxicology, 33, 92-98.

Hunt, J. R. (2003). Bioavailability of iron, zinc and other trace minerals from vegetarian diets. The American Journal of Clinical Nutrition, 78, 633-639.

Kanabrocki, E. L., Kanabrocki, J. A., Greco, J., Kaplan, E., \& Oester, Y. T. (1979). Instrumental analysis of trace elements in thumbnails of human subjects. The Science of the Total Environment, 13, 131-140.

King, J. C., Shames, D. M., \& Woodhouse, L. R. (2000). Zinc homeostasis in humans. The Journal of Nutrition, $130(5), 1360-1366$.

Lech, T., \& Sadlik, J. K. (2007). Copper concentration in body tissues and fluids in normal subjects of Southern Poland. Biological Trace Element Research, 118, 10-15.

Li, Y., Zou, X., Lv, J., Yang, L., Li, H., \& Wang, W. (2012). Trace elements in fingernails of healthy Chinese centenarians. Biological Trace Element Research, 145, 158- 165.

Mahler, D. J., Scott, A. F., Walsh, J. R., \& Haynie, G. (1970). A study of trace metals in fingernails and hair using neutron activation analysis. Journal of Nuclear Medicine, 11, 739-742.

Mehra, R., \& Juneja, M. (2005). Fingernails as biological indices of metal exposure. Journal of Bioscience, 30 , 253-257.

Mehra, R., \& Thakur, A. S. (2016). Relationship between lead, cadmium, zinc, manganese and iron in hair of environmentally exposed subjects. Arabian Journal of Chemistry, 9, 1214-1217.

Momen, A. A., Khalid, M. A. A., Elsheikh, M. A. A., \& Ali, D. M. H. (2015). Trace elements in scalp hair and fingernails as biomarkers in clinical studies. Journal of Health Specialties, 3(1), 28-34.

Nowak, B., \& Chmielnicka, J. (2000). Relationship of lead and cadmium to essential elements in hair, teeth, and nails of environmentally exposed people. Ecotoxicology and Environmental Safety, 62, 213-228.

Nyambura, J. N. (2012). Determination of levels of essential elements, lead and lead risk exposure factors in adult males using fingernails and scalp hair (master's thesis). Kenyatta University, Nairobi, Kenya.

Olabanji, S. O., Ajose, O. A., Makinde, N. O., Buoso, M. C., Ceccato, D., DePoli, M., \& Moschini, G. (2005). Characterization of human fingernail elements using PIXE techniques. Nuclear Instruments and Methods in Physics Research Section B, 240, 895-907. 
Parizanganeh, A., Zamani, A., Bijnavand, V., \& Taghilou, B. (2014). Human nail usage as a bio-indicator in contamination monitoring of heavy metals in Dizajabaad, Zanjan province-Iran. Journal of Environmental Health Science \& Engineering, 12, 147-155.

Rodushkin, I., \& Axelsson, M. D. (2000). Application of double focusing sector field ICP- MS for multielemental characterization of human hair and nails. Part II: A study of the inhabitants of northern Sweden. Science of Total Environment, 262, 21-36.

Samantha, G., Sharma, R., Roychowdhury, T., \& Chakraborti, D. (2004). Arsenic and other elements in hair, nails and skin-scales of arsenic victims in West Bengal, India. Science of the Total Environment, 326, 33-47.

Shrivastava, A., \& Gupta, V. B. (2011). Methods for the determination of limit of detection and limit of quantification of the analytical methods. Chronicles of Young Scientists, 2(1), 21-25.

Skalny, A. V., Skalnaya, M. G., Tinkov, A. A., Serebryanksky, E. P., Demidov, V. A., Lobanova, Y. N., Grabeklis, A. R. \& Nikonorov, A. A. (2015). Reference values of toxic trace elements content in occupationally nonexposed Russian population. Environmental Toxicology and Pharmacology, 409(1), 18-21.

Strachan, S. (2010). Trace elements. Current anaesthesia \& Critical Care, 21, 44-48.

Waseem, A., \& Arshad, J. (2016). A review of human biomonitoring studies of trace elements in Pakistan. Chemosphere, 163, 153-176.

Wee, B. S., \& Ebihara, M. (2017). Neutron activation analysis and assessment of trace elements in fingernail from residents of Tokyo, Japan. Sains Malaysiana, 46(4), 605-613.

World Health Organization (WHO). (2015). Human biomonitoring: Facts and figures. Retrieved January 15, 2018 , from http://www.euro.who.int/data/assets/pdf file/0020/276311/Human-biomonitoring-facts-figuresen.pdf.

Yoshida, M., Ogi, N., \& Iwashita, Y. (2011). Estimation of mineral and trace element intake in vegans living in Japan by chemical analysis of duplicate diets. Health, 3, 672-676. 